\title{
Protection from hydrogen peroxide stress relies mainly on AhpCF and KatA2 in Stenotrophomonas maltophilia
}

\author{
Li-Hua Li ${ }^{1,2 \dagger}{ }^{+}$, Yung-Luen Shih ${ }^{3,4,5 \dagger}{ }^{\dagger}$, Jing-Yun Huang ${ }^{6,7}$, Chao-Jung Wu' ${ }^{7}$ Yi-Wei Huang ${ }^{7}$, Hsin-Hui Huang ${ }^{7}$,
} Yu-Chieh Tsai $^{7}$ and Tsuey-Ching Yang ${ }^{7^{*}}$

\begin{abstract}
Background: Aerobically-grown bacteria can be challenged by hydrogen peroxide stress from endogenous aerobic metabolism and exogenously generated reactive oxygen species. Catalase (Kat), alkyl hydroperoxidase (Ahp), and glutathione peroxidase (Gpx) systems are major adaptive responses to $\mathrm{H}_{2} \mathrm{O}_{2}$ stress in bacteria. Stenotrophomonas maltophilia is a ubiquitous Gram-negative bacterium equipped with four Kats (KatA1, KatA2, KatMn, and KatE), one Ahp (AhpCF), and three Gpxs (Gpx1, Gpx2, and Gpx3). Here, we systematically investigated how the eight $\mathrm{H}_{2} \mathrm{O}_{2}$ scavenging genes differentially contribute to the low-micromolar levels of $\mathrm{H}_{2} \mathrm{O}_{2}$ generated from aerobic metabolism and high-millimolar levels of $\mathrm{H}_{2} \mathrm{O}_{2}$ from exogenous sources.

Methods: Gene expression was assessed and quantified by reverse transcription-PCR (RT-PCR) and real time quantitative PCR (qRT-PCR), respectively. The contribution of these enzymes to $\mathrm{H}_{2} \mathrm{O}_{2}$ stress was assessed using mutant construction and functional investigation.

Results: Of the eight genes, katA2, ahpCF, and gpx3 were intrinsically expressed in response to low-micromolar levels of $\mathrm{H}_{2} \mathrm{O}_{2}$ from aerobic metabolism, and the expression of katA2 and ahpCF was regulated by OxyR. AhpCF and KatA2 were responsible for alleviating aerobic growth-mediated low concentration $\mathrm{H}_{2} \mathrm{O}_{2}$ stress and AhpCF played a critical role for stationary-phase cells. KatA2 was upregulated to compensate for AhpCF in the case of ahpCF inactivation. After exposure to millimolar levels of $\mathrm{H}_{2} \mathrm{O}_{2}, \mathrm{katA2}$ and ahpCF were upregulated in an OxyR-dependent manner. KatA2 was the critical enzyme for dealing with high concentration $\mathrm{H}_{2} \mathrm{O}_{2}$. Loss-of-function of KatA2 increased bacterial susceptibility to high concentration $\mathrm{H}_{2} \mathrm{O}_{2}$.
\end{abstract}

Conclusions: AhpCF and KatA2 are key enzymes protecting S. maltophilia from hydrogen peroxide stress.

Keywords: Stenotrophomonas maltophilia, Catalase, Alkyl hydroperoxidase, Glutathione peroxidase, Hydrogen peroxide stress, OxyR regulator

\section{Background}

In aerobic bacteria, hydrogen peroxide $\left(\mathrm{H}_{2} \mathrm{O}_{2}\right)$ stress is endogenously generated by aerobic metabolism. Exogenous $\mathrm{H}_{2} \mathrm{O}_{2}$ stress can be generated by chemical processes, competing organisms, and host cells in the environment. Superoxide, $\mathrm{H}_{2} \mathrm{O}_{2}$, and hydroxyl radicals are three main reactive oxygen species (ROS) in aerobic bacteria. Unlike

\footnotetext{
* Correspondence: tcyang@ym.edu.tw

${ }^{\dagger}$ Li-Hua Li and Yung-Luen Shih contributed equally to this work.

${ }^{7}$ Department of Biotechnology and Laboratory Science in Medicine, National Yang-Ming University, Taipei, Taiwan

Full list of author information is available at the end of the article
}

superoxide and hydroxyl radicals, $\mathrm{H}_{2} \mathrm{O}_{2}$ is not a free radical and is less toxic to bacteria. However, distinct from superoxide and hydroxyl radicals, $\mathrm{H}_{2} \mathrm{O}_{2}$ can easily diffuse across cell membranes. Furthermore, hydroxyl radical is the most reactive ROS species and it can be readily generated from $\mathrm{H}_{2} \mathrm{O}_{2}$ in the presence of $\mathrm{Fe}^{2+}$ via the Fenton reaction, causing irreversible damage to bacteria [1]. Therefore, effective removal of $\mathrm{H}_{2} \mathrm{O}_{2}$ is critical for bacterial survival.

To prevent $\mathrm{H}_{2} \mathrm{O}_{2}$-mediated damage, aerobic bacterial pathogens must quickly convert $\mathrm{H}_{2} \mathrm{O}_{2}$ into other, less dangerous substances. The most common and efficient 
systems for bacteria to alleviate $\mathrm{H}_{2} \mathrm{O}_{2}$ stresses are an array of scavenging enzymes [2], including catalase (Kat), glutathione peroxidase (Gpx), and alkyl hydroperoxidase/alkyl hydroperoxide reductase (Ahp) [3]. Catalase directly catalyzes the decomposition of hydrogen peroxide without oxidizing the enzyme itself. Peroxidases detoxify $\mathrm{H}_{2} \mathrm{O}_{2}$ by oxidizing itself and rely on cellular reductants to revive them from the oxidized state. A bacterium can harbor an array of $\mathrm{H}_{2} \mathrm{O}_{2}$ scavenging enzymes, like KatG, KatE, AhpCF, and BtuE in E. coli [4], and KatA, KatB, KatC, AhpA, AhpB, AhpCF, and BtuE in $P$. aeruginosa [5]. The $\mathrm{H}_{2} \mathrm{O}_{2}$ scavenging enzymes may differentially function in response to different oxidative stress sources.

OxyR, a LysR family transcription factor, is a wellcharacterized regulator of the $\mathrm{H}_{2} \mathrm{O}_{2}$ response in Gramnegative bacteria [6]. OxyR contains a regulatory domain and a DNA binding domain. After sensing a $\mathrm{H}_{2} \mathrm{O}_{2}$ threat, OxyR undergoes secondary structure rearrangement by forming a disulfide bond between the two conserved cysteine residues in the regulatory domain, resulting in oxidized OxyR. The oxidized OxyR binds to the promoter region of the target gene via the DNA binding domain, modulating target gene expression as a transcriptional activator or repressor.

Stenotrophomonas maltophilia is an aerobic, Gramnegative, $\gamma$-proteobacterium that is widely distributed in the soil, water, plant rhizosphere, and hospital equipment [7]. It is also a pathogen that infects cystic fibrosis and immunocompromised patients [8]. Because of its diverse habitats, $S$. maltophilia is expected to be equipped with more effective $\mathrm{H}_{2} \mathrm{O}_{2}$ alleviation systems to adapt to different environmental niches. Analysis of the S. maltophilia genome sequence indicates the presence of many $\mathrm{H}_{2} \mathrm{O}_{2}$ scavenging enzymes, including four distinct Kats, three Gpxs, and one alkyl hydroperoxidase/alkyl hydroperoxide reductase system (AhpCF) [9]. Given that three systems contribute to neutralize $\mathrm{H}_{2} \mathrm{O}_{2}$ stresses, a defect in a single system can be compensated by the others. Therefore, a global investigation of the three systems, instead of focusing on one system, is likely to contribute more to our understanding of $\mathrm{H}_{2} \mathrm{O}_{2}$ detoxification in bacteria. To our knowledge, no previous studies have comprehensively investigated the function and interplay among the three antioxidant systems in S. maltophilia. This study aimed to provide this information and elucidate the role of these antioxidant enzymes in protecting bacteria against $\mathrm{H}_{2} \mathrm{O}_{2}$ stress from aerobic metabolism or exogenous sources.

\section{Methods}

\section{Bacterial strains, plasmid, and growth condition}

Table S1 lists the bacterial strains, plasmids, and PCR primers used in this study. All primers used in this study were designed based on the genome of S. maltophilia K279a.

\section{Construction of in-frame deletion mutants}

The strategy of two-step double cross-over homologous recombination was used for the construction of mutants used in this study. Two PCR amplicons, corresponding to upstream and downstream of the gene intended to delete, were amplified using the paired primer sets and subsequently cloned into pEX18Tc to yield the recombinant plasmids for mutants construction. The primer sets used are KatA1N-F/KatA1N-R and KatA1C-F/KatA1C-R for plasmid p $\Delta$ KatA1, KatA2N-F/KatA2N-R and KatA2C-F/ KatA2C-R for plasmid $\mathrm{p} \Delta$ KatA2, KatMnN-F/KatMnN-R and KatMnC-F/KatMnC-R for plasmid p $\Delta$ KatMn, KatENF/KatEN-R and KatEC-F/KatEC-R for plasmid $p \Delta K a t E$, AhpCN-F/AhpCN-R and AhpFC-F/AhpFC-R for plasmid $\mathrm{p} \Delta \mathrm{AhpCF}, \mathrm{Gpx} 1 \mathrm{~N}-\mathrm{F} / \mathrm{Gpx} 1 \mathrm{~N}-\mathrm{R}$ and Gpx1C-F/Gpx1C-R for plasmid $\mathrm{p} \Delta \mathrm{Gpx} 1$, Gpx2N-F/Gpx2N-R and Gpx2C-F/ Gpx2C-R for plasmid p $\Delta$ Gpx2, and Gpx3N-F/Gpx3N-R and Gpx3C-F/Gpx3C-R for plasmid p $\Delta \mathrm{Gpx} 3$ (Table S1). These pEX18Tc-derived plasmids were mobilized into KJ cells by conjugation and the transconjugants selection were performed as descried previously [10]. PCR and DNA sequencing were performed to confirm the correctness of mutants. Double, quadruple, and hepta mutants were constructed from single mutants by the same procedure.

\section{Construction of complementation plasmids pAhpCF and pKatA2}

The 2551-bp PCR amplicon containing intact ahpCF genes was obtained by PCR using the primer sets AhpCF-F and AhpCF-R and cloned into pRK415, yielding pAhpCF. An approximate 2.1-kb DNA fragment containing intact katA2 gene was obtained by PCR using primer sets KatA2N-F and KatA2C-R and cloned into pRK415, generating plasmid pKatA2.

\section{Dihydrochodamine 123 (DHR123) assay}

Overnight cultures were subcultured to fresh LB medium containing $0.9 \mu \mathrm{g} / \mathrm{ml}$ DHR123 with an initial $\mathrm{OD}_{450}$ of 0.15 . After a 5 -h and 24-h incubations, fluorescence was detected using $500 \mathrm{~nm}$ as the excitation wavelength and $550 \mathrm{~nm}$ as the emission wavelength.

\section{Reverse transcription-PCR (RT-PCR)}

The DNA-free RNA of logarithmic-phase S. maltophilia cells was extracted using Total RNA Extraction Kit Mini (ARROWTEC) and reverse transcribed to cDNA by High Capacity cDNA Reverse Transcription Kit (Applied Biosystems). The cDNA of $100 \mathrm{ng}$ was used as template for PCR with the primers indicated. The primer sets used were KatA1Q-F/R for katA1, KatA2Q-F/R for katA2, 
KatMnQ-F/R for katMn, KatEQ-F/R for katE, AhpCQ-F/ $\mathrm{R}$ for $a h p C, \mathrm{Gpx} 1 \mathrm{Q}-\mathrm{F} / \mathrm{R}$ for $g p x 1, \mathrm{Gpx} 2 \mathrm{Q}-\mathrm{F} / \mathrm{R}$ for $g p x 2$, and Gpx3Q-F/R for gpx3 (Table S1). PCR amplicons were visualized by agarose gel electrophoresis. To check the specificity of primer pairs, control PCRs were performed using the chromosome DNA as the template. Since smeX in S. maltophilia KJ is intrinsically quiescent [11], it was used as the negative control to assure RNA purity.

\section{Real time quantitative PCR (qRT-PCR)}

The cDNA prepared for the aforementioned RT-PCR assay was used as template for qRT-PCR. qRT-PCR was carried out by the ABI Prism 7000 Sequence Detection System (Applied Biosystems) according to the manufacturer's protocols. The $16 \mathrm{~s}$ rRNA gene was used as an internal control and the transcripts of genes assayed were normalized with the internal control using $\Delta \Delta C_{T}$ method [12]. Primers used for qRT-PCR were the same as those used for RT-PCR (Table S1). All experiments were performed in triplicate.

\section{Construction of promoter-xylE transcriptional fusion reporter plasmids}

Three DNA segments upstream and including the start codons of $g p x 3, k a t A 2$, and $a h p C$ were amplified by PCR using the primer sets of Gpx3N-F/Gpx3N-R, KatA2N-F/ KatA2N-R, and AhpCN-F/AhpCN-R, respectively (Table $\mathrm{S} 1)$. These PCR products were inserted into pRKxylE to place the amplicons upstream of $x y l E$, which encodes an enzyme with $\mathrm{C} 23 \mathrm{O}$ activity. These plasmids were referred to as $\mathrm{pGpx} 3_{\mathrm{xylE}}$, pKatA2 $2_{\mathrm{xylE}}$, and $\mathrm{pAhpC} \mathrm{xylE}_{\mathrm{x}}$, respectively.

\section{Determination of $\mathrm{C} 230$ activity}

Catechol 2, 3-dioxygenase $(\mathrm{C} 23 \mathrm{O})$, encoded by a $x y l E$ gene, catalyzes the hydrolysis of catechol into the yellow 2-hydroxymuconate semialdehyde, which can be quantitatively determined by spectrophotometric analysis at a wavelength of $375 \mathrm{~nm}$. C23O activity were determined spectrophotometrically at $375 \mathrm{~nm}$ as described previously [11]. The rate of hydrolysis was calculated by using $44,000 \mathrm{M}^{-1} \mathrm{~cm}^{-1}$ as the extinction coefficient. One unit of enzyme activity (U) was defined as the amount of $\mathrm{C} 23 \mathrm{O}$ that converts $1 \mathrm{nmole}$ catechol per min. The $\mathrm{C} 23 \mathrm{O}$ specific activity was expressed as $\mathrm{U} / \mathrm{OD}_{450 \mathrm{~nm}}$.

\section{Growth kinetic assay}

Overnight-cultured strain tested was inoculated into fresh $\mathrm{LB}$ medium at the initial $\mathrm{OD}_{450 \mathrm{~nm}}$ of 0.15 . The $\mathrm{OD}_{450 \mathrm{~nm}}$ readings were taken at interval of $3 \mathrm{~h}$ for a total time of $24 \mathrm{~h}$.

\section{$\mathrm{H}_{2} \mathrm{O}_{2}$ susceptibility test (disk diffusion assay)}

The strain tested was cultured to mid-log phase and adjusted to a concentration of $10^{7}$ cells $/ \mathrm{ml}$. A $100 \mu \mathrm{l}$ aliquot was spread evenly over the surface of a LB agar plates. A $10 \mu \mathrm{l}$ of $20 \% \mathrm{H}_{2} \mathrm{O}_{2}$ was spotted onto a sterile paper disk (6 $\mathrm{mm}$ in diameter) and the disk was placed on the center of plate. The diameter of growth inhibition zone around disk was measured after a 24-h incubation at $37^{\circ} \mathrm{C}$.

\section{Results}

Analysis of Kat, AhpC, and Gpx systems in S. maltophilia genome

The catalase (Kat), alkyl hydroperoxidase/alkyl hydroperoxide reductase (AhpCF), and glutathione peroxidase (Gpx) systems are three major and extensively reported enzymatic $\mathrm{H}_{2} \mathrm{O}_{2}$ elimination systems in several bacteria. Genome sequence analysis showed that four kat, one $a h p C F$, and three gpx genes existed in the genome of $S$. maltophilia K279a [9]: Smlt0372 (katA1), Smlt1385 (katA2), Smlt2537 (katMn), Smlt3583 (katE), Smlt08410840 (ahpCF), Smlt3183 (gpx1), Smlt3228 (gpx2), and Smlt4676 (gpx3). In this study, we aimed to assess the roles of the eight enzymes in alleviating hydrogen peroxide stress generated by endogenous aerobic metabolism or by exogenous sources.

\section{AhpCF and KatA2 contribute to scavenge micromolar $\mathrm{H}_{2} \mathrm{O}_{2}$, and AhpCF play a critical role for stationary-phase cells}

The intrinsic expression of the $\mathrm{H}_{2} \mathrm{O}_{2}$ scavenging enzyme genes was tested using reverse transcription-PCR (RTPCR). Of the eight genes tested, gpx3, katA2, and $a h p C$ transcripts were detected (Fig. 1a), suggesting that Gpx3, KatA2, and AhpCF may participate in the alleviation of endogenous $\mathrm{H}_{2} \mathrm{O}_{2}$ stress arising from bacterial aerobic metabolism. The expressions of gpx3, katA2, and $a h p C$ genes in the logarithmic and stationary phases were further assessed by qRT-PCR. The $a h p C$ expression was abundant compared to katA2 and gpx3 in logarithmic phase. The expression level of $a h p C$ was further increased in the stationary phase (Fig. 1b). These observations suggested a critical role for $a h p C$ in endogenous $\mathrm{H}_{2} \mathrm{O}_{2}$ stress alleviation.

OxyR is a well-known regulator response to $\mathrm{H}_{2} \mathrm{O}_{2}$ stress in several bacteria [13]. The regulatory role of OxyR in the intrinsic expression of gpx3, katA2 and $a h p C$ was assessed by qRT-PCR. The expression of $g p x 3$ was little affected by OxyR. The katA2 transcript was obviously decreased in the $\operatorname{oxy} R$ null mutant, indicating that OxyR is a positive regulator for the intrinsic expression of katA2. Nevertheless, OxyR acted as a repressor for the expression of $a h p C$ in aerobically-grown cells (Fig. 1c). This observation is peculiar since OxyR is a 
(A)

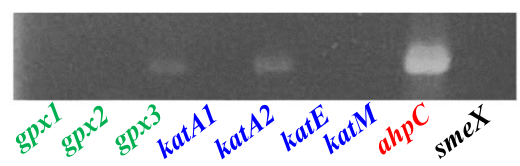

(B)

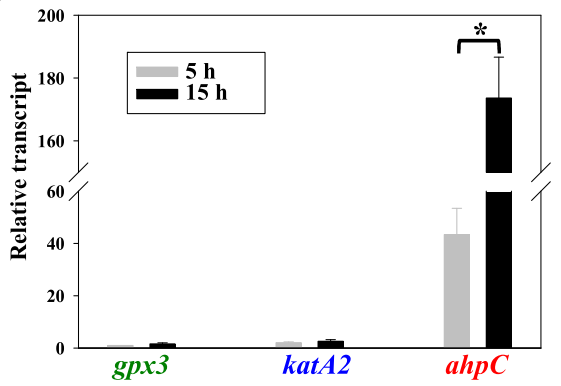

(C)

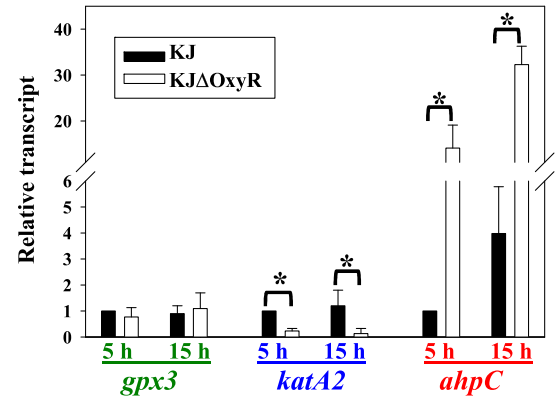

(D)

(E)
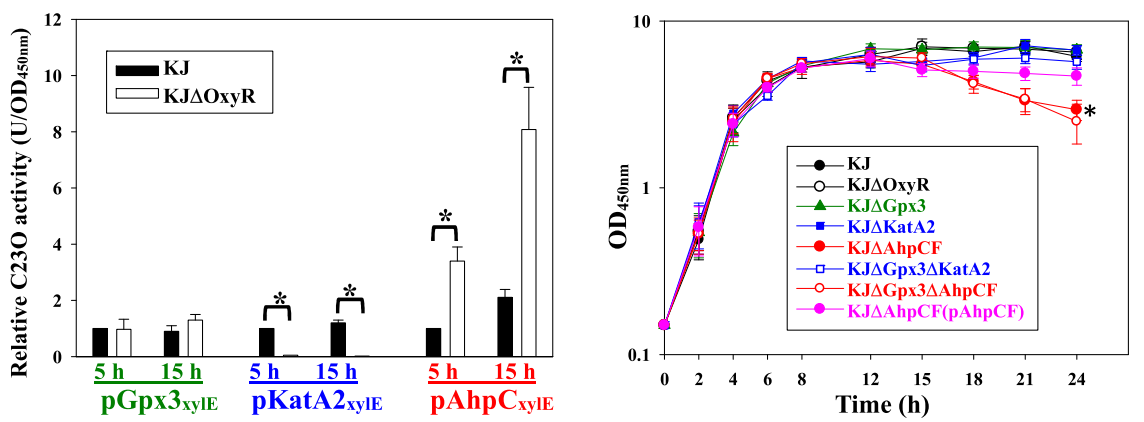

(F)

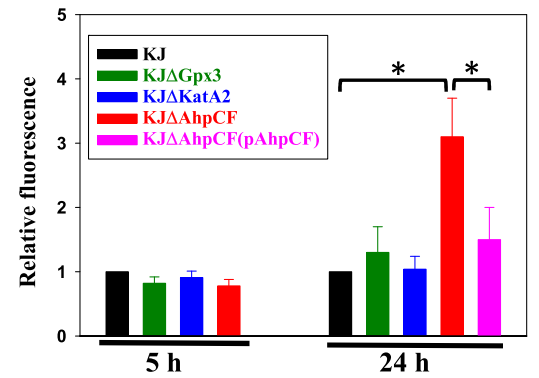

(G)

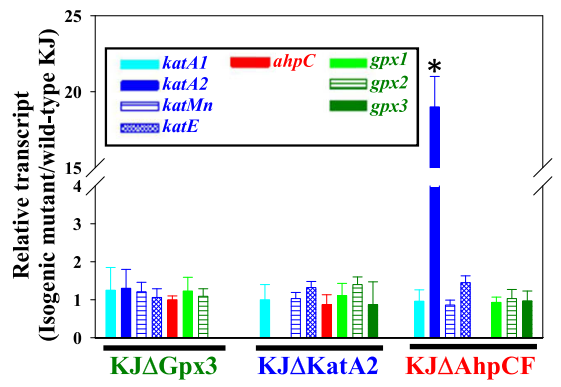

Fig. 1 (See legend on next page.)

positive regulator of antioxidant system widely reported in several bacteria $[13,14]$; thus we used promoter- $x y l E$ transcriptional fusion construct to recheck the role of OxyR in the expression of gpx3, katA2, and ahpC. The same conclusion was obtained from the results of promoter- $x y l E$ transcriptional fusion assay (Fig. 1d). To investigate the roles of $g p x 3$, katA2, and $a h p C F$ in the alleviation of endogenously aerobic metabolism-derived $\mathrm{H}_{2} \mathrm{O}_{2}$ stress, we investigated the aerobic growth of different single mutants (KJ $\Delta \mathrm{Gpx} 3$, KJ $\Delta \mathrm{KatA} 2$, and $\mathrm{KJ} \triangle \mathrm{AhpCF}$ ) and different combinations of double mutants (KJ $\Delta \mathrm{Gpx} 3 \Delta \mathrm{KatA} 2$ and $\mathrm{KJ} \Delta \mathrm{Gpx} 3 \Delta \mathrm{AhpCF}$ ). After several tries, we could not successfully obtain the double mutant of katA2 and aphCF genes. In addition, $\mathrm{KJ} \triangle \mathrm{OxyR}$ was also included. None of the tested mutants showed any observable growth restrictions in the logarithmic phase. However, $a h p C F$-associated mutants (KJ $\Delta \mathrm{AhpCF}$ and $\mathrm{KJ} \Delta \mathrm{Gpx} 3 \Delta \mathrm{AhpCF}$ ) exhibited gradual 
(See figure on previous page.)

Fig. 1 Roles of four catalases (KatA1, KatA2, KatE, and KatMn), one alkyl hydroperoxidase (AhpC), and three glutathione peroxidases (Gpx1, Gpx2, and $\mathrm{Gpx} 3$ ) in the alleviation of endogenous hydrogen peroxide stress. Bars represent the average values from three independent experiments. Error bars represent the standard error of the mean. ${ }^{*}, P<0.001$, significance calculated by Student's $t$ test. (a) Agarose gel electrophoresis of reverse transcription PCR (RT-PCR). Overnight-cultured S. maltophilia $\mathrm{KJ}$ was inoculated into fresh LB with an initial OD $450 \mathrm{~nm}$ of 0.15 and grown for $5 \mathrm{~h}$. The CDNAs were obtained using reverse transcription with random primers and PCR was performed using primer pairs (Table S1) targeting candidate genes. The smeX gene, which is not expressed in strain $\mathrm{KJ}$, is used as a control for DNA contamination during cDNA preparation. (b) The expression of gpx3, katA2, and ahpC genes in logarithmic- and stationary-phase wild-type $\mathrm{KJ}$ cells. Overnight culture of KJ cells was inoculated into fresh $L B$ with an initial $\mathrm{OD}_{450 \mathrm{~nm}}$ of 0.15 . Cells were grown aerobically for $5 \mathrm{~h}$ or $15 \mathrm{~h}$ before measuring $g p \times 3$, katA2, and ahpC transcripts using qRT-PCR. All values were normalized to gpx3 transcript of logarithmic-phase $\mathrm{KJ}$ cells. (c) Regulatory role of OxyR in the intrinsic expression levels of $g p \times 3, k a t A 2$, and $a h p C$ genes. Overnight cultures of $\mathrm{KJ}$ and $\mathrm{KJ} \Delta \mathrm{OxyR}$ cells were inoculated into fresh LB with an initial $\mathrm{OD}_{450 \mathrm{~nm}}$ of 0.15 . Cells were grown aerobically for $5 \mathrm{~h}$ or $15 \mathrm{~h}$ before measuring $g p \times 3$, katA2, and ahpC transcripts using qRT-PCR. All values were normalized to the transcript of logarithmic-phase KJ cells. (d) Regulatory role of OxyR in the intrinsic expression levels of $g p \times 3, k a t A 2$, and ahpC genes. Overnight cultures of bacteria cells $\left(K J\left(G p x 3_{x y l E}\right), K J\left(p K a t A 2_{x y \mid E}\right), K J\left(p A h p C_{x y l E}\right), K J \Delta O x y R\left(G p x 3_{x y l E}\right), K J O O x y R\left(p K a t A 2_{x y l E}\right)\right.$, and $K J \Delta O x y R$ $\left.\left(\mathrm{pAhpC}_{\text {xyl }}\right)\right)$ were inoculated into fresh $\mathrm{LB}$ with an initial $\mathrm{OD}_{450 \mathrm{~nm}}$ of 0.15 . Cells were grown aerobically for $5 \mathrm{~h}$ or $15 \mathrm{~h}$ before measuring the $\mathrm{C} 23 \mathrm{O}$ activity. All values were normalized to the activity in $\mathrm{KJ}$ cells. (e) Functions of OxyR, Gpx, Kat, and AhpCF systems in response to endogenously aerobic metabolism-derived $\mathrm{H}_{2} \mathrm{O}_{2}$ stress. The growth curves of $\mathrm{KJ}$ and its derived isogenic mutants were measured by reading $\mathrm{OD}_{450}$ at the time points as indicated. *, the growth difference of KJ $\triangle$ AhpCF and KJ $\triangle$ AhpCF (pAhpCF) at the 24-h time point was significant. (f) DHR 123 assay of wild-type $\mathrm{KJ}$ and mutants $\mathrm{KJ} \Delta \mathrm{Gpx3}, \mathrm{KJ} \Delta \mathrm{KatA} 2$, and $\mathrm{K} \Delta \Delta \mathrm{AhpCF}$. The bacterial cells tested were cultured in LB medium containing DHR 123 for $5 \mathrm{~h}$ and $24 \mathrm{~h}$, respectively, and the fluorescence at $550 \mathrm{~nm}$ was determined. The relative fluorescence is normalized to the fluorescence of wild-type

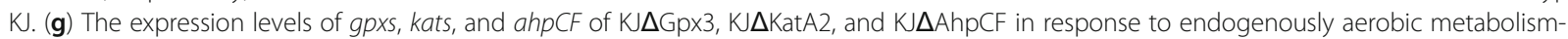
derived $\mathrm{H}_{2} \mathrm{O}_{2}$ stress. Bacteria cultured overnight (KJ, KJ $\Delta \mathrm{Gpx} 3, \mathrm{KJ} \Delta \mathrm{KatA} 2$, and $\mathrm{KJ} \Delta \mathrm{AhpC}$ ) were inoculated into fresh $L B$ with an initial $\mathrm{OD}_{450 \mathrm{~nm}}$ of 0.15 and grown for $5 \mathrm{~h}$. The katA1, katA2, katMn, katE, ahpC, gpx1, gpx2, and gpx3 transcripts were measured using qRT-PCR. The relative transcription level for each gene was expressed as the ratio of mutant to wild-type

reduction of cell density in the stationary phase, and this compromise was not observed when $\operatorname{ahpCF}$ genes were complemented (Fig. 1e).

To assess the relatedness of deletion mutant phenotypes to the intracellular $\mathrm{H}_{2} \mathrm{O}_{2}$ concentrations, the intracellular $\mathrm{H}_{2} \mathrm{O}_{2}$ concentrations of wild-type $\mathrm{KJ}$ and mutants $\mathrm{KJ} \Delta \mathrm{Gpx} 3, \mathrm{KJ} \Delta \mathrm{KatA} 2$, and $\mathrm{KJ} \Delta \mathrm{AhpCF}$ in the logarithmic $(5 \mathrm{~h})$ and the stationary phases $(24 \mathrm{~h})$ were determined by dihydrochodamine 123 (DHR123) assay. DHR123 is used for the detection of intracellular ROS and can detect $\mathrm{H}_{2} \mathrm{O}_{2}$ in the presence of endogenous peroxidases. The presence of ROS oxidizes DHR123 to the fluorescent derivative rhodamine 123 . Thus, the intracellular $\mathrm{H}_{2} \mathrm{O}_{2}$ concentration is proportional to the fluorescence intensity. The fluorescences detected from the logarithmic-phase $\mathrm{KJ} \Delta \mathrm{Gpx} 3$, KJ $\Delta \mathrm{KatA} 2$, and $\mathrm{KJ} \Delta \mathrm{AhpCF}$, and from the stationary-phase $\mathrm{KJ} \Delta \mathrm{Gpx} 3$ and $\mathrm{KJ} \Delta \mathrm{Kat} \mathrm{A} 2$ were comparable to that from wild-type KJ (Fig. 1f). Nevertheless, stationary-phase KJ $\Delta \mathrm{AhpCF}$ cells had higher fluorescence relative to stationary-phase KJ cells (Fig. 1f), correlated well with stationary-phase growth compromise of $a h p C F$ associated mutants (Fig. 1e).

Given functional redundancy in these $\mathrm{H}_{2} \mathrm{O}_{2}$-alleviating enzymes, we considered the possibility that some of these enzymes may be induced to compensate for the absence of one. To test this hypothesis, the transcription levels of the eight genes were measured using qRT-PCR in the deletion mutants $\mathrm{KJ} \Delta \mathrm{Gpx} 3, \mathrm{KJ} \Delta \mathrm{KatA} 2$, and $\mathrm{KJ} \Delta \mathrm{AhpCF}$. Inactivation of gpx3 or katA2 alone did not significantly affect the expression of the other seven genes. However, the expression of katA2 in $\mathrm{KJ} \triangle \mathrm{AhpCF}$ cells increased by $19 \pm 2$-fold compared to parental KJ cells (Fig. 1g).

\section{KatA2 and AhpCF, mainly KatA2, contribute to scavenge millimolar $\mathrm{H}_{2} \mathrm{O}_{2}$}

The impact of exogenous $\mathrm{H}_{2} \mathrm{O}_{2}$ stress on the expression of $\mathrm{H}_{2} \mathrm{O}_{2}$ scavenging enzymes was investigated by qRTPCR. Of the eight genes assessed, katA2 and $a h p C$ were upregulated after a $2 \mathrm{mM} \mathrm{H}_{2} \mathrm{O}_{2}$ challenge (Fig. 2a).

We also assessed the possibility of compensatory expression in $\mathrm{KJ} \Delta \mathrm{KatA} 2$ and $\mathrm{KJ} \Delta \mathrm{AhpCF}$ in the presence of exogenous $\mathrm{H}_{2} \mathrm{O}_{2}$ stress. In either $\mathrm{KJ} \Delta \mathrm{KatA} 2$ or $\mathrm{KJ} \triangle \mathrm{AhpCF}$, the expression levels of the remaining seven $\mathrm{H}_{2} \mathrm{O}_{2}$ scavenging enzymes in response to $\mathrm{H}_{2} \mathrm{O}_{2}$ challenge were hardly affected compared to that in wild-type KJ (Fig. 2a).

We investigated the regulatory role of $\mathrm{OxyR}$ in exogenous $\mathrm{H}_{2} \mathrm{O}_{2}$-mediated katA2 and $a h p C$ upregulation with the $\mathrm{H}_{2} \mathrm{O}_{2}$ concentrations ranged from 0 to $2 \mathrm{mM}$. When the exogenous $\mathrm{H}_{2} \mathrm{O}_{2}$ concentration was as low as $1 \mu \mathrm{M}$, there was no impact on the amounts of katA2 and $a h p C$ transcripts. In response to $5 \mu \mathrm{M}$ or $100 \mu \mathrm{M} \mathrm{H}_{2} \mathrm{O}_{2}$ challenge, katA2 transcript had a mild (approximately 2-3 fold), but not significant increment; however, $a h p C$ transcript was upregulated (Fig. 2b \& c). When the challenged $\mathrm{H}_{2} \mathrm{O}_{2}$ concentration was higher than $250 \mu \mathrm{M}$, the katA2 and $a h p C$ transcripts were significantly increased (Fig. 2b \& c). In addition, katA2 expression was positively regulated by OxyR without or with the treatment of $\mathrm{H}_{2} \mathrm{O}_{2}$ (Fig. $2 \mathrm{~b})$. However, OxyR regulatory role in $\operatorname{ahpC}$ expression was $\mathrm{H}_{2} \mathrm{O}_{2}$ concentration dependent, as a repressor when $\mathrm{H}_{2} \mathrm{O}_{2}$ concentration was less than $5 \mu \mathrm{M}$ and as an activator when $\mathrm{H}_{2} \mathrm{O}_{2}$ concentration was higher than $100 \mu \mathrm{M}$ (Fig. 2c). 


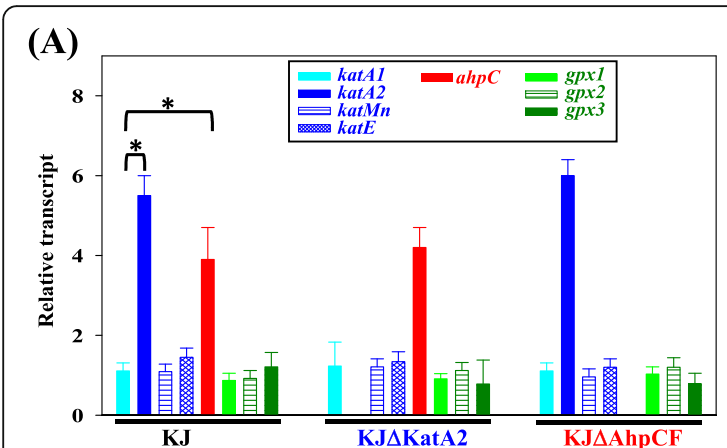

(B)

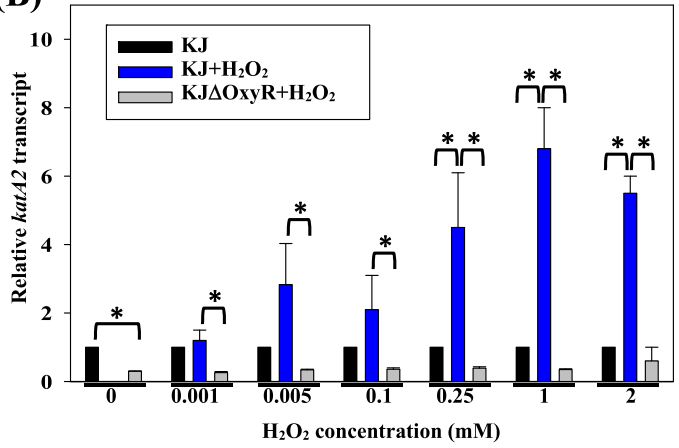

(C)

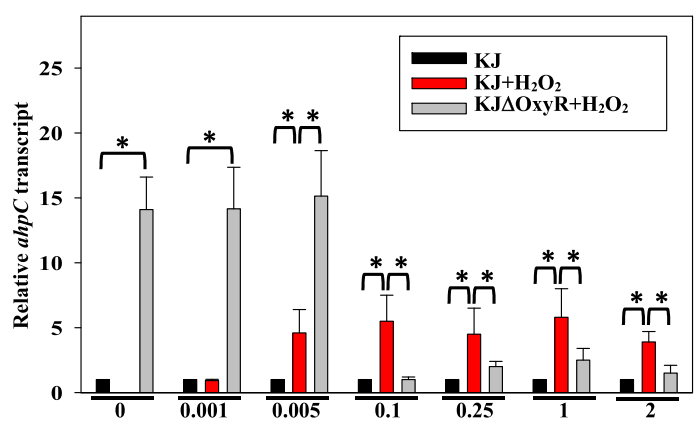

(D)

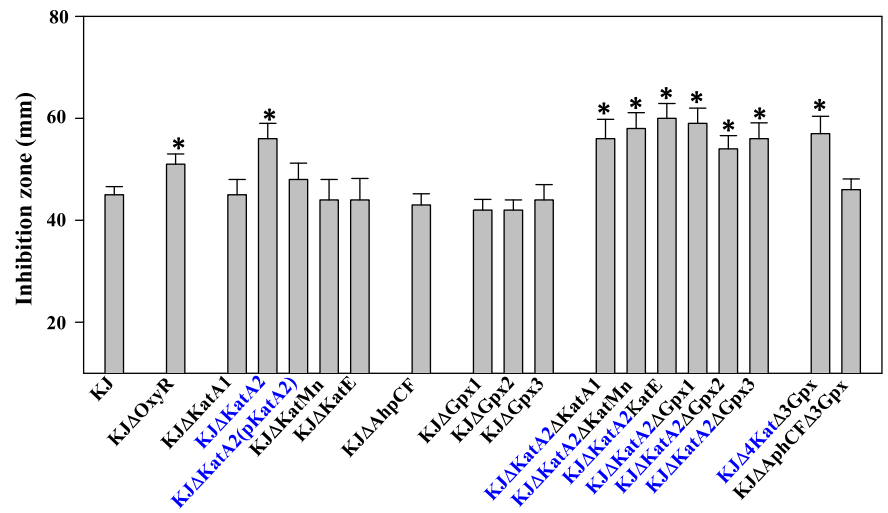

Fig. 2 Roles of four catalases (KatA1, KatA2, KatE, and KatMn), one alkyl hydroperoxidase (AhpC), and three glutathione peroxidases (Gpx1, Gpx2, and $\mathrm{Gpx} 3$ ) in the alleviation of exogenous hydrogen peroxide stress. Bars represent the average values from three independent experiments. Error bars represent the standard error of the mean. ${ }^{*}, P<0.001$, significance calculated by Student's $t$ test. (a) Expression of $\mathrm{H}_{2} \mathrm{O}_{2}$-hydrolyzing enzyme genes in the strains $\mathrm{K}, \mathrm{K} \Delta \triangle \mathrm{KatA} 2$, and $\mathrm{KJ} \Delta \mathrm{AhpC}$ after hydrogen peroxide challenge. The bacteria tested were treated with $2 \mathrm{mM} \mathrm{H}_{2} \mathrm{O}_{2}$ for 10 min before measuring katA1, katA2, katMn, katE, ahpC, gpx1, gpx2, and gpx3 transcription using qRT-PCR. All values were normalized to individual transcripts obtained from untreated $\mathrm{KJ}$ cells. (b) Regulatory role of OxyR in katA2 expression in response to exogenous $\mathrm{H}_{2} \mathrm{O}_{2}$ stress. The $\mathrm{KJ}$ and $\mathrm{KJ} \Delta \mathrm{OxyR}$ cells were untreated or treated with different $\mathrm{H}_{2} \mathrm{O}_{2}$ concentration as indicated for 10 min before measuring katA2 transcript using qRT-PCR. All values were normalized to katA2 transcript obtained from untreated KJ cells. (c) Regulatory role of OxyR in ahpC expression in response to exogenous $\mathrm{H}_{2} \mathrm{O}_{2}$ stress. The $\mathrm{KJ}$ and $\mathrm{KJ} \Delta \mathrm{OxyR}$ cells were untreated or treated with different $\mathrm{H}_{2} \mathrm{O}_{2}$ concentration as indicated for 10 min before measuring ahpC transcript using qRT-PCR. All values were normalized to ahpC transcript obtained from untreated $\mathrm{KJ}$ cells. (d) $\mathrm{H}_{2} \mathrm{O}_{2}$ susceptibility test of $\mathrm{KJ}$ and its derived isogenic mutants. The bacterial cell suspension tested was uniformly spread onto $\mathrm{MH}$ agar, and a sterile filter paper with $10 \mu$ lof $20 \% \mathrm{H}_{2} \mathrm{O}_{2}$ was placed on the agar. After a $24-\mathrm{h}$ incubation at $37^{\circ} \mathrm{C}$, the growth inhibition zone was measured

To investigate the role of the eight enzymes in exogenous $\mathrm{H}_{2} \mathrm{O}_{2}$ detoxification, we performed an $\mathrm{H}_{2} \mathrm{O}_{2}$ susceptibility test of $\mathrm{KJ}$-derived mutants containing single deletions of the katA1, katA2, katMn, katE, $a h p C F, g p x 1, g p x 2$, and $g p x 3$ genes. In addition, we assessed the $\mathrm{H}_{2} \mathrm{O}_{2}$ susceptibility of $\mathrm{KJ} \Delta \mathrm{OxyR}$. Except for $\mathrm{KJ} \Delta \mathrm{KatA} 2$ and $\mathrm{KJ} \Delta \mathrm{OxyR}$, the remaining seven mutants displayed $\mathrm{H}_{2} \mathrm{O}_{2}$ susceptibility that was similar to wild-type $\mathrm{KJ}$ (Fig. 2d). KJ $\Delta$ KatA2 was more sensitive to $\mathrm{H}_{2} \mathrm{O}_{2}$ than wild-type $\mathrm{KJ}$ (Fig. 2d), and complementation of the mutant with pKatA2, a plasmid containing an intact katA2 gene, restored $\mathrm{H}_{2} \mathrm{O}_{2}$ resistance (Fig. 2d). KJ $\Delta$ OxyR was also more sensitive to $\mathrm{H}_{2} \mathrm{O}_{2}$ than wild-type $\mathrm{KJ}$, but not as severe as $\mathrm{KJ} \Delta$ KatA2 (Fig. 2d). Next, we assessed whether additional mutations in $\mathrm{KJ} \Delta \mathrm{KatA} 2$ could enhance $\mathrm{H}_{2} \mathrm{O}_{2}$ sensitivity by constructing several combinations of multiple genes deletion mutants using $\mathrm{KJ} \Delta \mathrm{KatA} 2$ as a parental strain and performing $\mathrm{H}_{2} \mathrm{O}_{2}$ sensitivity assays in all mutants. $\mathrm{H}_{2} \mathrm{O}_{2}$ sensitivity was hardly augmented compared to $\mathrm{KJ} \Delta \mathrm{KatA} 2$ in all mutants tested, although 4 catalase genes and three $g p x$ genes were simultaneously inactivated (KJ $\Delta 4 \mathrm{Kat} \Delta 3 \mathrm{Gpx}$ ) (Fig. 2d).

It has been reported that OxyR of E. coli binds to the $5^{\prime}$ promoter-operator regions of target genes at a conserved motif comprised of four ATAG elements spaced at 10-bp intervals $[15,16]$. Since OxyR is involved in the $\mathrm{H}_{2} \mathrm{O}_{2}$-induced upregulation of katA2 and $\operatorname{ahpCF}$, we surveyed the upstream region of the ahpCF and katA2 genes. We discovered ATAG-N14-ATAG and ATAGN19-ATAG elements near the $a h p C F$ and katA2 promoters (Fig. S1).

\section{Discussion}

$\mathrm{H}_{2} \mathrm{O}_{2}$ stress is an inevitable challenge for aerobic bacteria. Respiratory bursts account for up to $87 \%$ of the 
total $\mathrm{H}_{2} \mathrm{O}_{2}$ production in aerobically-grown Escherichia coli, and intracellular $\mathrm{H}_{2} \mathrm{O}_{2}$ from aerobic metabolism normally remains at low-micromolar ranges $(<4 \mu \mathrm{M})$ [17]. In the course of infection, $\mathrm{H}_{2} \mathrm{O}_{2}$ levels can reach up to millimolar concentrations because of the oxidative burst generated by host immune cells [2]. To avoid $\mathrm{H}_{2} \mathrm{O}_{2}$ toxicity, bacteria have equipped themselves with several scavenging enzymes to maintain intracellular $\mathrm{H}_{2} \mathrm{O}_{2}$ at nanomolar concentrations [4, 17]. AhpCF and catalase systems are scavenging enzymes that are extensively conserved in several bacterial lineages [2]. AhpCF is more kinetically efficient than catalases at scavenging $\mathrm{H}_{2} \mathrm{O}_{2}$, but its activity is more easily saturated than that of catalases [4]. Therefore, AhpCF is the primary scavenger when $\mathrm{H}_{2} \mathrm{O}_{2}$ is in the low-micromolar range, and catalase activity predominates when the cell reaches millimolar levels of $\mathrm{H}_{2} \mathrm{O}_{2}$ [4]. This paradigm has been observed in a variety of organisms [4], and we highlight our findings in this study to add new evidence to this paradigm.

AhpCF of S. maltophilia was expressed in the logarithmic phase and further upregulated in the stationary phase (Fig. 1b), implying that higher AhpCF activity is required for $S$. maltophilia to deal with $\mathrm{H}_{2} \mathrm{O}_{2}$ stress in the stationary phase. This inference is supported by the observation in Fig. 1e and Fig. 1f, since $a h p C F$-associated mutants (KJ $\Delta \mathrm{AhpCF}$ and $\mathrm{KJ} \Delta \mathrm{Gpx} 3 \Delta \mathrm{AhpCF}$ ) exhibited compromised stationary-phase growth (Fig. 1e) and the higher $\mathrm{H}_{2} \mathrm{O}_{2}$ concentration was observed in the stationary-phase $\mathrm{KJ} \triangle \mathrm{AhpCF}$ cells (Fig. 1f). Inactivation of katA2 did not affect the expression of other $\mathrm{H}_{2} \mathrm{O}_{2}$ scavenging enzymes (Fig. 1g) and did not compromise bacterial aerobic growth (Fig. 1e), indicating that AhpCF alone is potent enough to deal with the lowmicromolar $\mathrm{H}_{2} \mathrm{O}_{2}$ stress. In contrast, upregulation of KatA2 is needed to attain normal logarithmic growth in the case of $a h p C F$ inactivation (KJ $\triangle \mathrm{AhpCF}$ ) (Fig. 1e and g). Collectively, for an aerobically-grown S. maltophilia, AhpCF and KatA2 are key enzymes responsible for the alleviation of logarithmic-phase $\mathrm{H}_{2} \mathrm{O}_{2}$ stress and AhpCF system plays a critical role in dealing with the stationary-phase $\mathrm{H}_{2} \mathrm{O}_{2}$ stress.

When bacteria encounter exogenous $\mathrm{H}_{2} \mathrm{O}_{2}$ stress up to the high-micromolar, even millimolar level, ahpCF and katA2 are upregulated (Fig. 2a), linking the contribution of AhpCF and KatA2 to alleviate high concentration $\mathrm{H}_{2} \mathrm{O}_{2}$. However, neither KJ $\Delta$ KatA2 nor $\mathrm{KJ} \Delta \mathrm{AhpCF}$ exhibited compensatory expression of other enzymes tested in response to $2 \mathrm{mM} \mathrm{H}_{2} \mathrm{O}_{2}$ challenge (Fig. 2a), suggesting that there should be other non-enzymatic systems contributing to deal with millimolar $\mathrm{H}_{2} \mathrm{O}_{2}$ stress in addition to KatA2 and AhpCF. However, we also observed that the katA2-associated mutants, but not the other mutants, had a compromised $\mathrm{H}_{2} \mathrm{O}_{2}$ tolerance (Fig. 2d), indicating that among the enzymes tested in this study, KatA2 is the dominant enzyme for the alleviation of high concentration $\mathrm{H}_{2} \mathrm{O}_{2}$ stress.

Vattanaviboon's group has investigated the role of AhpCF of S. maltophilia in response to high level of $\mathrm{H}_{2} \mathrm{O}_{2}$ stress recently [18], and their conclusions are not totally consistent with our findings. They demonstrated that inactivation of $a h p C$ rendered S. maltophilia more resistant to $300-900 \mathrm{mM} \mathrm{H}_{2} \mathrm{O}_{2}$ than parental strain, which was attributed to the enhanced KatA2 expression and activity [18]. However, our results showed that the expression of katA2 in the 2 $\mathrm{mM} \mathrm{H}_{2} \mathrm{O}_{2}$-treated $a h p C F$ mutant $(\mathrm{KJ} \triangle \mathrm{AhpCF})$ was comparable to that of parental strain (KJ) (Fig. 2a). The discrepancy may be attributed to different stress intensities (the treated $\mathrm{H}_{2} \mathrm{O}_{2}$ concentration and time intervals), different experiment designs for $\mathrm{H}_{2} \mathrm{O}_{2}$ tolerance evaluation, and strain variation. If the $a h p C$ mutant indeed gains a survival superiority against $\mathrm{H}_{2} \mathrm{O}_{2}$ at concentrations commonly used in a hospital, the prevalence of $a h p C$ mutant in the clinical S. maltophilia isolates should be an interesting issue to study.

The OxyR regulatory role is another interesting finding in this study. OxyR is an $\mathrm{H}_{2} \mathrm{O}_{2}$-sensing transcriptional regulator that is generally conserved in Gram-negative bacteria [13, 14]. In this study, $\mathrm{H}_{2} \mathrm{O}_{2}$ dose-dependent regulation was observed in S. maltophilia OxyR. OxyR functioned as a positive regulator for the expression of katA2 either at micromolar or at millimolar $\mathrm{H}_{2} \mathrm{O}_{2}$ concentrations (Fig. 1c, d, \& b). However, OxyR played a double-edged role in the regulation of $a h p C F$ expression. OxyR repressed ahpCF expression at low-micromolar $\mathrm{H}_{2} \mathrm{O}_{2}$ concentrations $\left(\mathrm{H}_{2} \mathrm{O}_{2}\right.$ concentration $\left.<5 \mu \mathrm{M}\right)$ (Fig. 1c, d \& c), but activated ahpCF expression when $\mathrm{H}_{2} \mathrm{O}_{2} \quad \mathrm{H}_{2} \mathrm{O}_{2}$ concentration higher than $100 \mu \mathrm{M}$ (Fig. 2c). This is uncommon because OxyR generally promotes ahpCF expression in other bacteria [19]. Herein, we proposed two possibilities to explain this observation. (i) Two different OxyR activated forms may form dependent on the $\mathrm{H}_{2} \mathrm{O}_{2}$ concentrations (different symbols for active OxyR in Fig. 3a and b), which may have different impacts on ahpCF expression (Fig. 3). (ii) Members of OxyR regulon triggered by low $\mathrm{H}_{2} \mathrm{O}_{2}$ concentrations are not totally the same as those triggered by high $\mathrm{H}_{2} \mathrm{O}_{2}$ concentrations, and different OxyR regulon member(s) regulate(s) the ahpCF expression in micromolar and millimolar $\mathrm{H}_{2} \mathrm{O}_{2}$ concentrations, respectively (Fig. $3 \mathrm{a}$ and $\mathrm{b}$ ). The negative regulatory role of OxyR in ahpCF expression (Fig. 1c, d) may help $S$. maltophilia to cope with the endogenous $\mathrm{H}_{2} \mathrm{O}_{2}$ stress in the case of the loss of OxyR function. When oxyR 
(A)
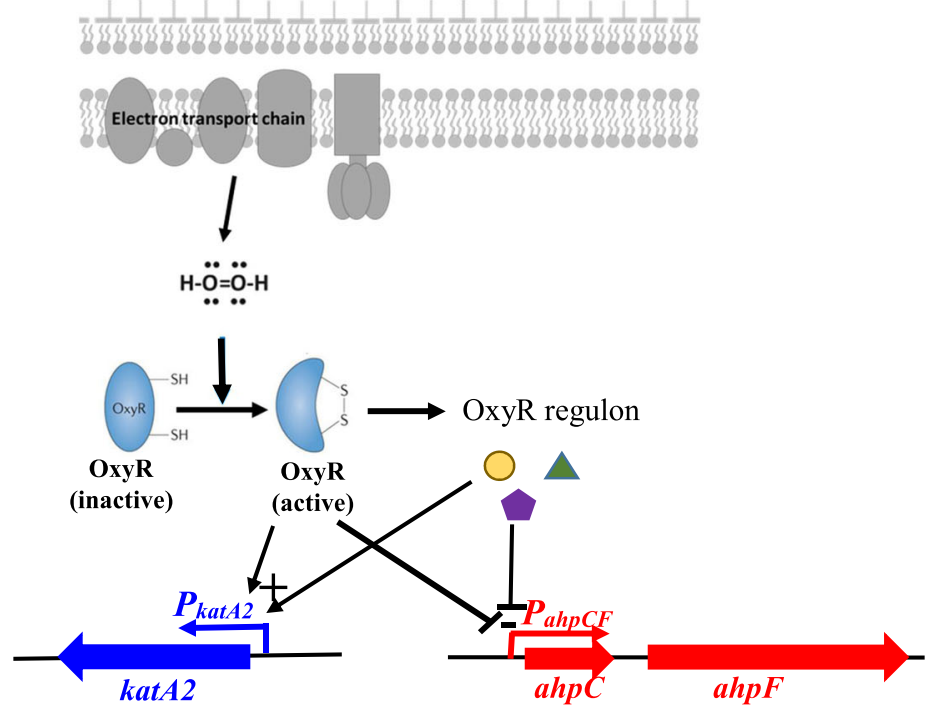

(B)
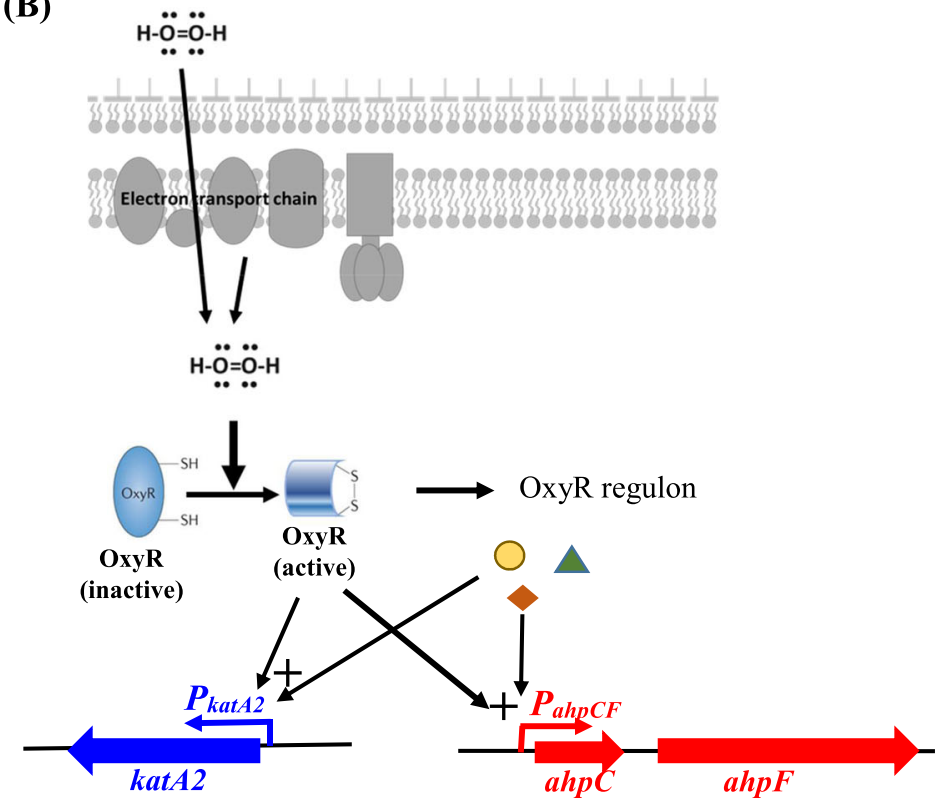

Fig. $3 \mathrm{~A}$ model for $\mathrm{H}_{2} \mathrm{O}_{2}$-dependent and OxyR-mediated transcription regulation of ahpCF and katA2 genes in response to different concentrations of $\mathrm{H}_{2} \mathrm{O}_{2}$ stress in S. maltophilia. (a) Low-micromolar $\mathrm{H}_{2} \mathrm{O}_{2}$ is generated by bacterial aerobic metabolism and OxyR is oxidized at a specific "sensing" cysteine residue by $\mathrm{H}_{2} \mathrm{O}_{2}$. The activated OxyR represses the expression of ahpCF operon and increases the expression of katA2 gene, either directly or indirectly. (b) When bacteria encounter exogenous $\mathrm{H}_{2} \mathrm{O}_{2}$ stress and the intracellular $\mathrm{H}_{2} \mathrm{O}_{2}$ concentration increases to millimolar levels, activated OxyR activates the expression of ahpCF operon and katA2 gene, either directly or indirectly

is inactivated, the shortage of KatA2 activity can be compensated by upregulated AhpCF, which can maintain normal $\mathrm{H}_{2} \mathrm{O}_{2}$ detoxification. This may be the reason why $\mathrm{KJ} \Delta \mathrm{OxyR}$ displayed comparable growth with wild-type $\mathrm{KJ}$, but $\mathrm{KJ} \Delta \mathrm{AhpCF}$ had a growth compromise in the stationary phase (Fig. 1e).

\section{Conclusion}

AhpCF and KatA2 are two main enzymes to differentially protect $S$. maltophilia from the hydrogen peroxide stress. AhpCF and KatA2 participate the alleviation of low-micromolar level $\mathrm{H}_{2} \mathrm{O}_{2}$, and $\mathrm{AhpCF}$ has a crucial role for stationary-phase cells; in contrast, KatA2 is the major contributor for dealing with the millimolar level $\mathrm{H}_{2} \mathrm{O}_{2}$. OxyR acts as a positive regulator for the expression of katA2. However, the regulatory role of $\mathrm{OxyR}$ in the $a h p C F$ expression depends on the $\mathrm{H}_{2} \mathrm{O}_{2}$ concentration, as a repressor in $\mathrm{H}_{2} \mathrm{O}_{2}$ of low-micromolar level and as an activator in $\mathrm{H}_{2} \mathrm{O}_{2}$ of millimolar level. 


\section{Supplementary information}

Supplementary information accompanies this paper at https://doi.org/10. 1186/s12929-020-00631-4.

Additional file 1 Table S1. Bacterial strains, plasmids and primers used in this study.

Additional file 2 Fig. S1. Analysis of putative OxyR binding motifs in the upstream regions of katA2 and $a h p C$ genes.

\section{Abbreviations}

Ahp: Alkyl hydroperoxidase; DHR123: Dihydrochodamine 123;

Gpx: Glutathione peroxidase; Kat: Catalase; QRT-PCR: Real time quantitative

PCR; ROS: Reactive oxygen species; RT-PCR: Reverse transcription-PCR

\section{Acknowledgements}

Not applicable.

\section{Author's contributions}

LHL and YLS conceived the experiment and analyzed data. JYH, CJW, YWH, $\mathrm{HHH}$, and YCT performed the experiments, generated and collected the data. TCY designed the experiment, interpreted the data, and wrote the manuscript. All authors read and approved the final manuscript.

\section{Funding}

This study was funded by grant MOST 108-2320-B-010-032-MY3 from the Ministry of Science and Technology of Taiwan, grants V108B-037 and V109C195 from Taipei Veterans General Hospital, and grant 2019SKHAND007 from the Shin Kong Wu Ho-Su Memorial Hospital, Taipei, Taiwan.

\section{Availability of data and materials}

Data and materials related to this study are available upon request.

\section{Ethics approval and consent to participate}

Not applicable.

\section{Consent for publication}

Not applicable.

\section{Competing interests}

The authors declare that they have no competing interests.

\section{Author details}

${ }^{1}$ Department of Pathology and Laboratory Medicine, Taipei Veterans General Hospital, Taipei, Taiwan. ${ }^{2}$ Program of Medical Biotechnology, Taipei Medical University, Taipei, Taiwan. ${ }^{3}$ Department of Pathology and Laboratory Medicine, Shin Kong Wu Ho-Su Memorial Hospital, Taipei, Taiwan. ${ }^{4}$ School of Medical Laboratory Science and Biotechnology, Taipei Medical University, Taipei, Taiwan. ${ }^{5}$ School of Medicine, College of Medicine, Fu-Jen Catholic University, New Taipei City, Taiwan. ${ }^{6}$ Department of Laboratory Medicine, Chang-Gung Memorial Hospital, LinKou, Taiwan. ${ }^{7}$ Department of Biotechnology and Laboratory Science in Medicine, National Yang-Ming University, Taipei, Taiwan.

Received: 25 July 2019 Accepted: 17 February 2020

Published online: 25 February 2020

\section{References}

1. Cabiscol E, Tamarit J, Ros J. Oxidative stress in bacteria and protein damage by reactive oxygen species. Int Microbiol. 2000;3:2-8.

2. Mishra S, Imlay J. Why do bacteria use so many enzymes to scavenge hydrogen peroxide? Arch Biochem Biophys. 2012;525:145-60.

3. Poole LB. Bacterial defenses against oxidants: mechanistic features of cysteine-based peroxidases and their flavoprotein reductases. Arch Biochem Biophys. 2005;433:240-54.

4. Seaver LC, Imlay JA. Alkyl hydroperoxide reductase is the primary scavenger of endogenous hydrogen peroxide in Escherichia coli. J Bacteriol. 2001;183: 7173-81.

5. Ochsner UA, Vasil ML, Alsabbagh E, Parvatiyar K, Hassett DJ. Role of the Pseudomonas aeruginosa oxyR-recG operon in oxidative stress defense and
DNA repair: OxyR-dependent regulation of $k a t B-a n k B$, ahpB, and $a h p C-a h p F$. J Bacteriol. 2000;182:4533-44.

6. Demple B. Regulation of bacterial oxidative stress genes. Annu Rev Genet. 1991;25:315-37.

7. Alavi P, Starcher MR, Thallinger GG, Zachow C, Muller H, Berg G. Stenotrophomonas comparative genomics reveals genes and functions that differentiate beneficial and pathogenic bacteria. BMC Genomics. 2014;15: 482.

8. Parkins MD, Floto RA. Emerging bacterial pathogens and changing concepts of bacterial pathogenesis in cystic fibrosis. J Cyst Fibros. 2015;14: 293-304.

9. Crossman LC, Gould VC, Dow JM, Vernikos GS, Okazaki A, Sebaihia M, et al. The complete genome, comparative and functional analysis of Stenotrophomonas maltophilia reveals an organism heavily shielded by drug resistance determinants. Gen Biol. 2008;9:R74.

10. Yang TC, Huang YW, Hu RM, Huang SC, Lin YT. AmpD, is involved in expression of the chromosomal L1 and L2 $\beta$-lactamases of Stenotrophomonas maltophilia. Antimicrob Agents Chemother. 2009;53: 2902-7.

11. Chen $\mathrm{CH}$, Huang CC, Chung TC, Hu RM, Huang YW, Yang TC. Contribution of resistance-nodulation-division efflux pump operon smeU1-V-W-U2-X to multidrug resistance of Stenotrophomonas maltophilia. Antimicrob Agents Chemother. 2011;55:5826-33.

12. Livak KJ, Schmittgen TD. Analysis of relative gene expression data using real-time quantitative PCR and the 2-(Delta Delta $C(T)$ ) method. Methods. 2001;25:402-8.

13. Dubbs JM, Mongkolsuk S. Peroxide-sensing transcriptional regulators in bacteria. J Bacteriol. 2012;194:5495-503.

14. Chen H, Xu G, Zhao Y, Tian B, Lu H, Yu X, Xu Z, Ying N, Hu S, Hua Y. A nove OxyR sensor and regulator of hydrogen peroxide stress with one cysteine residue in Deinococcus radiodurans. PLoS One. 2008;3(2):e1602.

15. Tartaglia LA, Gimeno CJ, Storz G, Ames BN. Multidegenerate DNA recognition by the OxyR transcriptional regulator. J Biol Chem. 1992;267: 2038-45.

16. Toledano MB, Kullik I, Trinh F, Baird PT, Schneider TD, Storz G. Redoxdependent shift of OxyR-DNA contacts along an extended DNA-binding site: a mechanism for differential promoter selection. Cell. 1994;78:897-909.

17. González-Flecha B, Demple B. Metabolic sources of hydrogen peroxide in aerobically growing Escherichia coli. J Biol Chem. 1995;270:13681-7.

18. Charoenlap N, Jiramonai L, Chittrakanwong J, Tunsakul N, Mongkolsuk S, Vattanaviboon P. Inactivation of ahpC renders Stenotrophomonas maltophilia resistant to the disinfectant hydrogen peroxide. Antonie Van Leeuwenhoek. 2019;112:809-14.

19. Hassett DJ, Alsabbagh E, Parvatiyar K, Howell ML, Wilmott RW, Ochsner UA. A protease-resistant catalase, KatA, released upon cell lysis during stationary phase is essential for aerobic survival of a Pseudomonas aeruginosa oxyR mutant at low cell densities. J Bacteriol. 2000;182:4557-63.

\section{Publisher's Note}

Springer Nature remains neutral with regard to jurisdictional claims in published maps and institutional affiliations.

\section{Ready to submit your research? Choose BMC and benefit from:}

- fast, convenient online submission

- thorough peer review by experienced researchers in your field

- rapid publication on acceptance

- support for research data, including large and complex data types

- gold Open Access which fosters wider collaboration and increased citations

- maximum visibility for your research: over $100 \mathrm{M}$ website views per year

At $\mathrm{BMC}$, research is always in progress.

Learn more biomedcentral.com/submissions 